\title{
内頸動脈硬膜輪近傍動脈瘤の手術手技と外科解剖について
}

\author{
京島 和彦, 小林 茂昭, 宜保 浩彦 \\ 一之瀬 良樹, 湧 井 健 治
}

\section{Surgical Techniques and Anatomy of the Juxta-DURAL RING Aneurysms}

Kazuhiko Kyoshima, M.D., Shigeaki Kobayashi, M.D., Hirohiko Gibo, M.D.,

Yoshiki Ichinose, M.D., and Kenji Wakui, M.D.

Department of Neurosurgery, Shinshu University School of Medicine, Matsumoto, Japan

Summary : Internal carotid artery (ICA) aneurysms arising from around the carotid dural ring are of considerable surgical interest due to their anatomical features and technical difficulties. With the recent refinement of microsurgical techniques, their management has changed from conservative surgery to direct neck clipping. Different authors call the ICA aneurysms arising near the dural ring by different names such as "ventral internal carotid aneurysms", "paraclinoid aneurysms" or "infraclinoidal aneurysms." Some of these aneurysms were considered unclippable or associated with disastrous results when surgically approached.

We report a subgroup of ICA aneurysms located around the carotid dural ring which we call Juxta-DURAL RING aneurysms. These aneurysms are classified into three types: intradural type (intradural aneurysm), carotid cave type (carotid cave aneurysm) and infraclinoid type (infraclinoid aneurysm). The intradural aneurysm arises from the ICA distal to the origin of the ophthalmic artery and correspond to so-called IC-ophthalmic aneurysms which are juxtaposed on the dural ring. The carotid cave aneurysm is located in a small dural recess (carotid cave) proximal to the origin of the ophthalmic artery and at the angiographical genu. The infraclinoid aneurysm may be included in the conventional intracavernous sinus aneurysms, and is located extradurally in the infraclinoid space close to the dural ring. From the point of view of surgical anatomy, clipping of these aneurysms requires essentially the same surgical techniques; complete removal of the anterior clinoid process, unroofing of the optic canal, complete opening of the dural ring, and exposure of the surgical genu and axilla of the ICA via the pterional approach. Utilizing these techniques they are clippable with relative ease. In this paper, our surgical technique is discussed giving explanations of surgical anatomy and clinical cases.

\section{はじめに}

従来の内頸一眼動脈瘤の中で眼動脈起始部に近いものほ ど時に思わぬ手術的困難さを生ずる。また内頸動脈の硬膜 貫通部 (硬膜輪, dural ring)に近いものは海綿静脈洞内に 動脈瘤が存在するものとしてクリッピング不可能とされて
Key words :

- Juxta-DURAL RING aneurysm

- surgical anatomy

- carotid cave aneurysm

- infraclinoid aneurysm

- cavernous sinus
きた。今回は既に報告した carotid cave aneurysm(9)10)11) の経験をふまえて, 内頸動脈の硬膜貫通部近傍に発生する 動脈瘤について外科解剖も含め, 我々の行っている手術手 技について述べる. 


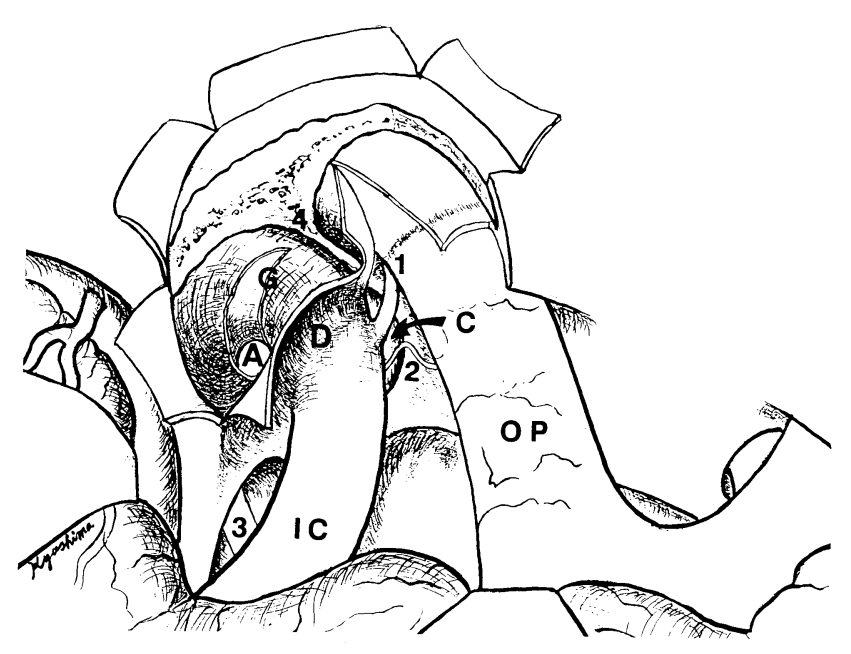

Fig. 1 Schematic drawing of surgical anatomy of the operative field obtained by left pterional approach after removal of the optic roof and anterior clinoid process. Note that the internal carotid artery (ICA) penetrates the dural ring obliquely, the carotid cave is located ventrally where the superior hypophyseal artery originates from the ICA, the genu of the ICA is running horizontally, and the carotid ring adheres to the ICA tightly in the dorsal to lateral side. A: axilla of ICA, C: carotid cave, D: carotid dural ring, G: surgical genu of ICA, OP: optic nerve, IC: internal carotid artery.

1: ophthalmic artery, 2: superior hypophyseal artery, 3: oculomotor nerve, 4: optic strut.

\section{内頸動脈硬膜輪近傍の外科解剖}

Fig. 1は頭部を対側に約 45 度回転させた左 pterional approach で前床突起を切除し，視神経管を開放した実際 の術野に即した外科解剖の模式図である。内頸動脈を硬膜 内より硬膜外にたどると, 内頸動脈は外側に孤を描きなが ら内頸動脈の長軸に対して斜めに硬膜を貫通している ${ }^{9)}$ 10) 11) 15)。この硬膜貫通部が内頸動脈硬膜輪 (carotid dural ring)である.この貫通部での動脈と硬膜の線維性癒着は 内頸動脈の背側から外側壁では強度であるが，腹側壁では 脆弱である 7) 9) 10)11)。この dural ring 部は蝶形骨の carotid groove 内にあり (正面像では 1 時から 6 時), 硬膜の陥凹 部は carotid caveを形成する。いいかえれば carotid cave の先端が脆弱な dural ring を形成していることになる.ま た内頸動脈が斜めに dural ring を貫通していることから carotid caveの部分は硬膜内であるが，内頸動脈の長軸に 対して反対側は硬膜外となる. carotid caveには内頸動脈 より分枝する数本の上下垂体動脈 (superior hypophyseal artery)が認められる ${ }^{1) 6}$.

前床突起を切除すると海綿静脈洞の上壁が露出されるが,

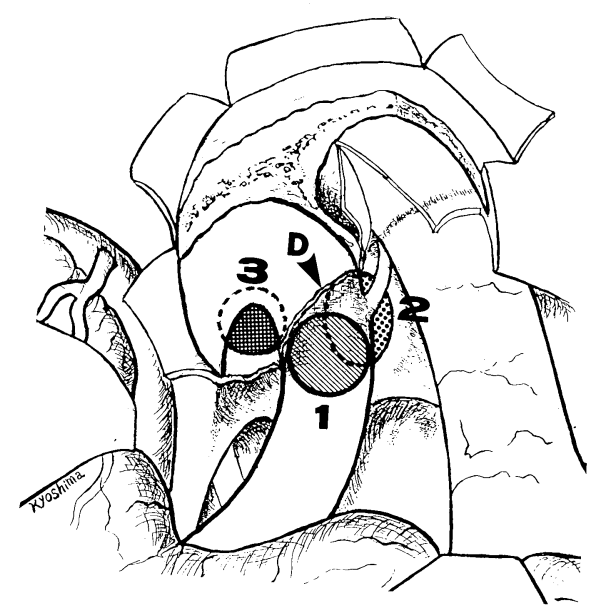

Fig. 2 Classification and anatomical relationship of the Juxta-DURAL RING aneurysms.

1: intradural aneurysm, 2: carotid cave aneurysm, 3: infraclinoid aneurysm. D: carotid dural ring.

この部分は infraclinoid space と呼び，海綿静脈洞上壁を 切除したときに認められる内頸動脈部を infraclinoid segment of carotid artery と呼ぶ. infraclinoid segmentのう ち, 湾曲が最も強い部分を外科的内頸動脈膝部 (surgical genu of the carotid artery)といい, Fischer のC $\mathrm{C}_{3}$ 部 $^{4)} に ほ$ ぼ相当する．実際の術野ではほぼ水平に見える，さらにこ の弯曲部の内側を内頸動脈腋窩部 (axilla) と呼んでいる.

\section{内頸動脈硬膜輪近傍動脈瘤の分類}

この内頸動脈の硬膜貫通部近傍に発生する動脈瘤を内頸 動脈硬膜輪近傍動脈瘤 (Juxta-DURAL RING aneurysm) と呼び, 解剖学的位置関係から次の 3 つに分類する Fig. $2,4)$.

\section{1. 硬膜内動脈瘤 (intradural aneurysm)}

dural ring に近接する硬膜内に発生する動脈瘤で，その ネックが通常眼動脈起始部より遠位側にある。動脈瘤の術 野での発育方向は主に腹側，まれに背側に認められる。こ の動脈瘤は前述のごとく dural ring が斜めに内頸動脈を囲 んでいるので，硬膜内であっても dural ring の開放を行わ ないと, クリップのブレイドが硬膜にあたって十分なネッ ククリッピングができない(Fig. 5-2)。この部の動脈瘤手 術に挍いても dural ringの開放が必須である.

\section{2. 内頸動脈窩動脈瘤 (carotid cave aneurysm)}

carotid caveに発生する動脈瘤で, 動脈瘤ネックは眼動 脈より近位側に位置する。前述の intradural aneurysm と 


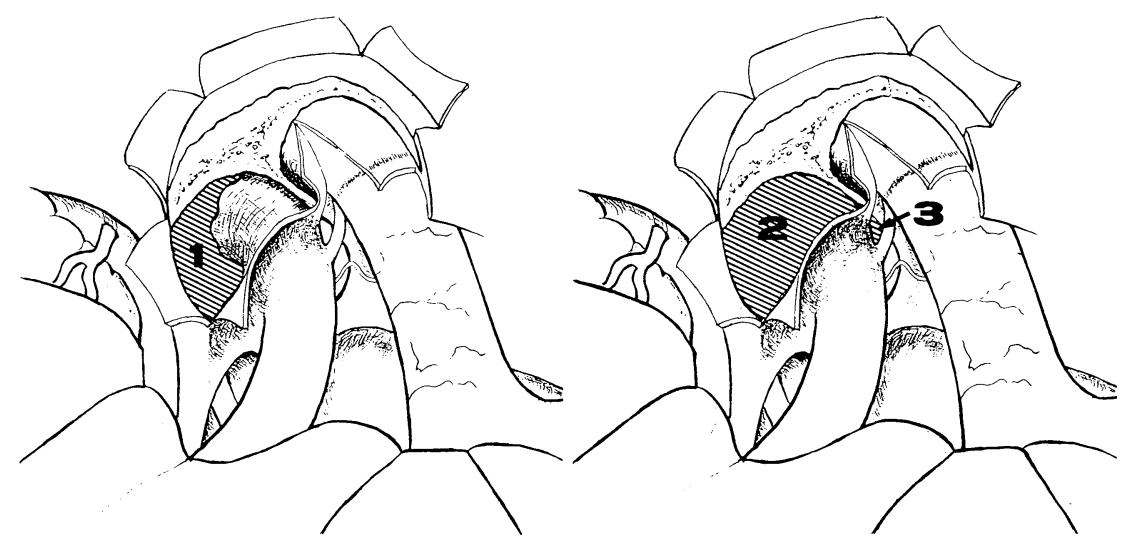

Fig. 3 Schematic drawing of various kinds of development of the infraclinoid cavernous sinus. 1: partial infraclinoid development of cavernous sinus, 2 : entire infraclinoid development, 3: extensive development into the carotid cave.

後述の infraclinoid aneurysm の中間型とも考えられる. 動脈瘤の術野での発育方向は解剖学的位置関係からすべて 腹側である。

\section{3. 前床突起下動脈瘤 (infraclinoid aneurysm)}

infraclinoid segment に発生する硬膜外動脈瘤で, 硬膜 外より dural ringに近接するものである。従来の海綿静脈 洞内動脈瘤に含まれるものであるが，我々の手術経験から すると内頸動脈の infraclinoid segment をとりまく海綿静 脈洞の発達は一様でなく, 部分的なものから carotid cave に及ぶものまで認められる(Fig. 3)。このことから我々は この部の動脈瘤を infraclinoid aneurysm と呼んでいる.

Fig. 4 は, Juxta-DURAL RING aneursym 30 例 (intradural aneurysm 13 例, carotid cave aneurysm 14 例, infraclinoid aneurysm 3 例)の検討から, 血管写側面像にお ける各動脈瘤のネックの位置を示した模式図である.

\section{手 術手技}

Juxta-DURAL RING aneurysm の手術では，この部の 外科解剖学的関係から基本的に共通した手術手技が必要と される.

最初に頸部で内頸動脈を確保し, 頭部を対側に約45度回 転させた pterional approach ${ }^{18)} に て$ sphenoid ridge を硬膜 外に十分に削った後, 硬膜を開きシルビウス裂および内頸 動脈槽を開放し，硬膜内操作により前床突起を完全切除し， さらに視神経管および dura propriaの開放を行う。視神 経管の unroofing に際しては不必要に視神経管部を越えて 内側まで骨を削らないようにすることが，篩骨洞の開放に

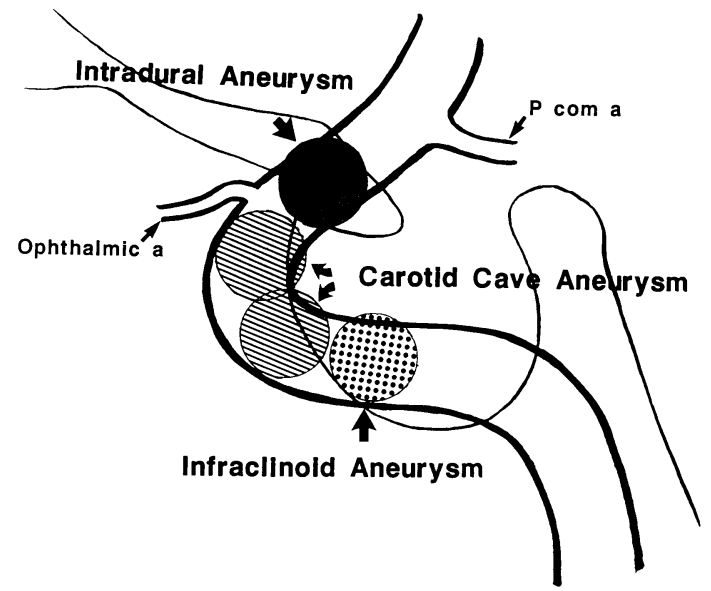

Fig. 4 Locations of Juxta-DURAL RING aneurysms: the sites of aneurysmal necks as confirmed on the lateral views of the postoperative angiograms. Note that the carotid cave aneurysms are located at the angiographical genus $\left(\mathrm{C}_{3}\right)$ and proximally to the origin of the ophthalmic artery, the intradural aneurysm distally to the ophthalmic artery, and the infraclinoid aneurysm proximally to the carotid cave aneurysms. P com a: posterior communicating artery.

伴う髄液漏防止のために大切である. 眼動脈は視神経に沿 って露出する. infraclinoid space で海綿静脈洞を開き, 内頸動脈の surgical genu, axilla を露出した後 dural ring をほぼ全周にわたって剥離開放する，海綿静脈洞からの出 血はオキシセル綿などを内頸動脈に沿って近位側にパッキ ングすること，および頭部挙上することで容易に止血でき る.またこの部の海綿静脈洞は前述のごとく時に部分的に しか認められないことがあるが，このような場合でも内頸 


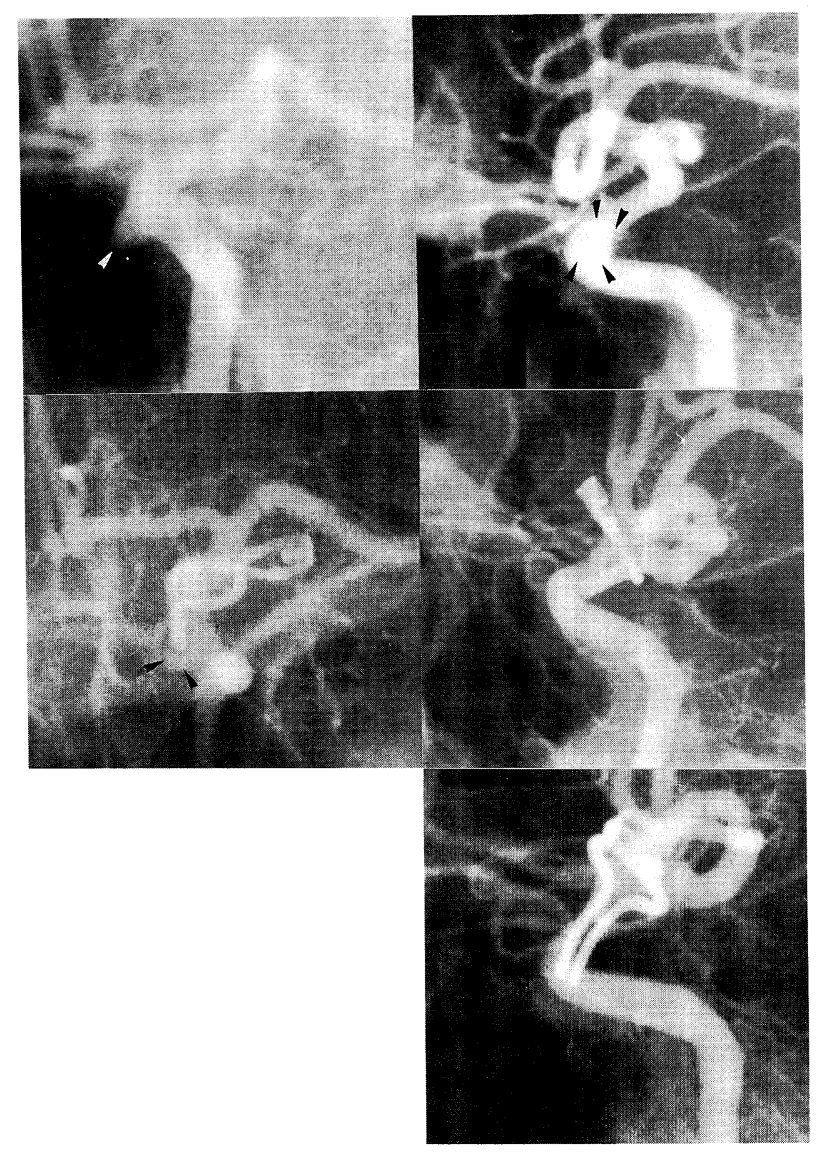

Fig. 5-1 Case 1. Left carotid cave aneurysm. Left carotid angiograms. Left column showing the anteroposterior (A-P) view and right column the lateral view. Arrowheads indicate the aneurysm. Upper: Preoperative angiograms. Note that the aneurysm is located medially on the A-P view. Middle: After the first operation, the aneurysm is only partially obliterated. Lower: After the second operation, the aneurysm is completely obliterated by an angled ring clip with curved blades. Note that the site of aneurysm is precisely confirmed by the position of the clip blade located at the angiographical genu.

動脈を被う膜を切除し内頸動脈を露出することが dural ring の切離開放を容易にする．動脈瘤が術野の腹側に存 在する場合, 内頸動脈の生理的湾曲を損なわないためにブ レイドが側方に弯曲した直角リングクリップが有用である.

上下垂体動脈は，特に太くなければ犠牲にしても問題な いようである．前床突起切除，視神経管の開放により生じ た硬膜欠損部には，開頭部より側頭筋片あるいは骨膜片を あてておく。

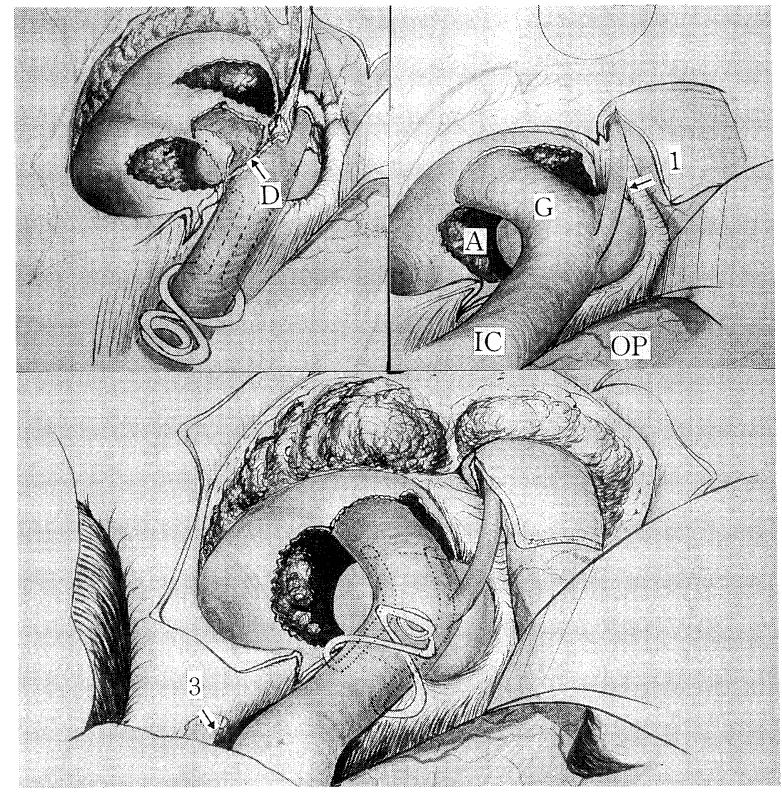

Fig. 5-2 Operative drawing of Case 1 at the second operation. Upper left: Note that the dural ring blocks proximal advancement of clip blades to obliterate the aneurysm. Upper right: The aneurysm is exposed by freeing the dural ring circumferentially. Lower: New designed curved-blade ring clip is applied to completely obliterate the aneurysm. Abbreviations are the same as in Fig. 1.

\section{症例}

<症例 1>44 歳, 男性. carotid cave aneurysm

一過性脳虚血にて発症し，脳血管撮影にて左 carotid cave aneurysm を認めた。側面血管写では動脈瘤ネックは 眼動脈分岐部より近位側で内頸動脈サイフォンの最大弯曲 部に認められた。正面血管写では動脈瘤が内側に認められ る(Fig. 5-1). 左 pterional approach にて前床突起切除, 視神経管の開放を行い, genu, axilla を露出させ，直角り ングクリップにてクリッピングを行った．術後の血管写で 動脈瘤の中枢側に動脈瘤ネックの残存を認めたため再手術 を行った．初回手術では動脈輪の開放を行わなかったため， 硬膜にクリップのブレイド先端が当たっていた，dural ring を全周にわたり剝離し，動脈瘤ネックを完全に露出 しブレイドが側方に弯曲したリングクリップにて再クリッ ピングを行った(Fig. 5-2)。これは初期の症例で, dural ringの開放の重要性を認識させられた症例である.

$<$ 症例 $2>34$ 歳, 女性. intradural aneurysm, carotid cave aneurysm.

脳底動脈瘤破裂によるクモ膜下出血にて発症し，脳血管 写にて左に intradural aneurysm (Fig. 6-1), 右に carotid 


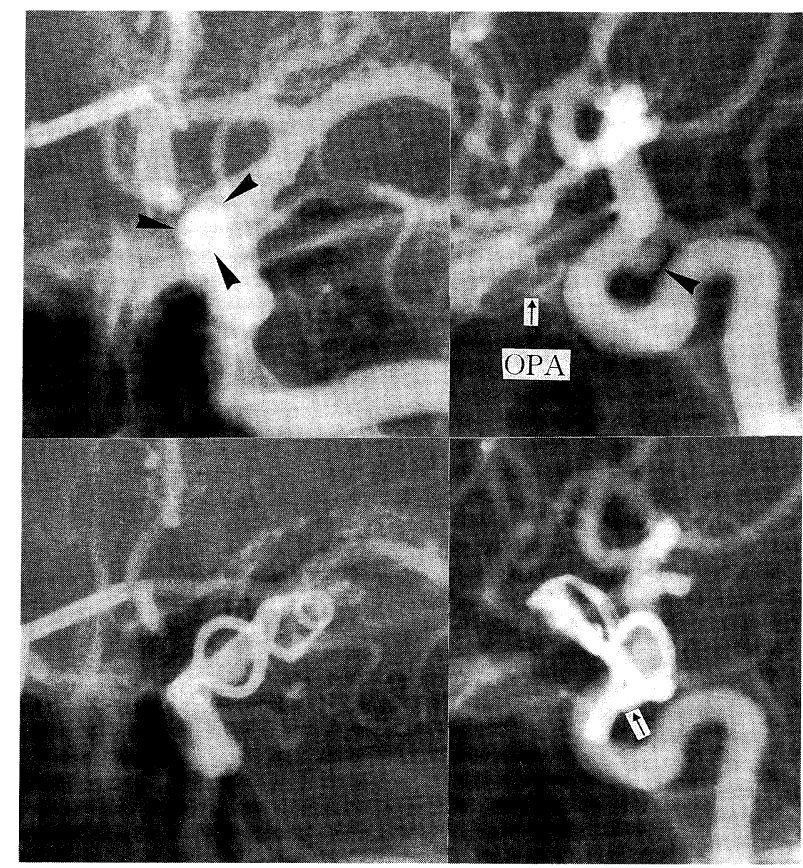

Fig. 6-1 Case 2. Left intradural aneurysm. Left carotid angiograms. (Basilar aneurysm was previously clipped) Upper: Preoperative angiograms on A-P and lateral views. Note that the aneurysm is located distally to the ophthalmic artery on the lateral view. Arrowheads indicate the aneurysm. OPA: ophthalmic artery. Lower: Postoperative angiograms. Arrow shows a clip for this intradural aneurysm.

cave aneurysm (Fig. 7-1) が認められた. intradural aneurysmは眼動脈より遠位側にあり, carotid cave aneurysm は眼動脈分岐部より中枢側で内頸動脈サイフォ ン最大弯曲部に認められた。側面血管写における最大弯曲 部, $\mathrm{C}_{3}$ サイフォン部を angiographical genuとすると, こ の genuのところに認められるのが carotid cave aneurysm ということになる．血管写側面像に掞ける位置関係は，術 後のクリップの位置でさらに明確に理解される(Fig. 7-1). 脳底動脈瘤の術後約 3 力月で, 最初に左 intradural aneurysmの手術を行った。動脈瘤は術野の腹側にあり dural ring 周辺の硬膜と接していた. 硬膜輪を全周切離し, 側弯ブレイドの直角リングクリップにてクリッピングを行 った(Fig. 6-2). 1 カ月後, 右 carotid cave aneurysmの手 術を行った (Fig. 7-2). 術後血管写は両側の動脈瘤手術後 に行った。

$<$ 症例 $3>67$ 歳, 女性. infraclionoid aneurysm.

下垂体腫瘍の患者で血管写にて動脈瘤が認められた。本 例は解剖のところで述べたが, 内頸動脈の長軸に対して carotid cave の反対側にある infraclinoid aneurysm の症例

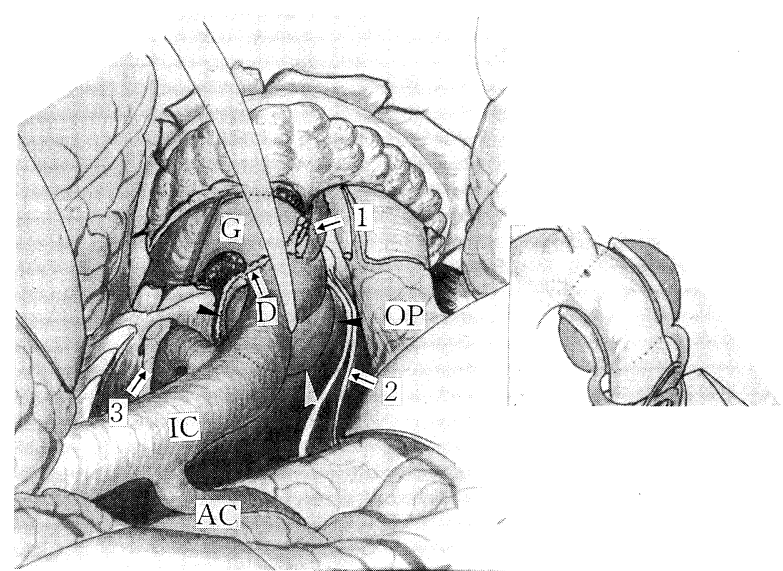

Fig. 6-2 Operative drawing. Aneurysm is located just distally to the carotid dural ring and was clipped with a cruved-blade ring clip after opening the dural ring. Abbreviations are the same as in Fig. 1. Arrow heads indicate the aneurysm. AC: anterior cerebral artery.

である，術前血管写では最大弯曲部にあり側面血管写から は carotid cave aneurysm と考えられるが, 正面像では内 側に動脈瘤は認められず，術後の正面像でのクリップの位 置から判断するとむしろ動脈瘤は外側に位置している

(Fig. 8-1). 術中所見では carotid cave の反対側で dural ringより近位側にある infraclinoid aneurysmであった

(Fig. 8-2). 術後血管写ではネックの一部が残っている.

\section{考察}

carotid cave aneurysmに拈前床突起の完全切除, 視神経管の unroofing, dural ring 開放の必要性について は既に報告したが911)， carotid cave aneurysm 以外にも 同様の手術手技が必要であった動脈瘤を検討し，これらを Juxta-DURAL RING aneurysm としてまとめた.これら の Jaxta-DURAL RING aneurysm は基本的に同一の手術 手技により容易に clipping 可能であった。

\section{1. 手術手技}

動脈瘤手術の基本は動脈瘤ネックの近位側および遠位側 を十分に露出確保することにある. 従来はdural ring 近傍 に発生する動脈瘤に対しては前床突起の切除あるいは視神 経管の開放さらにはdural ring の開放が不十分なため, ネ ックの確認あるいは十分なネック近位側の確保が困難で, クリッピング不可能, あるいは親血管の閉塞, ネックを残 すなどの不完全クリッピングに終わっていたものと思われ る. Juxta-DURAL RING aneurysmの手術においては, 内頸動脈が斜めにdural ring 貫通しているという解剖学 的特殊性から, 前床突起の完全切除, 視神経の開放, さら 


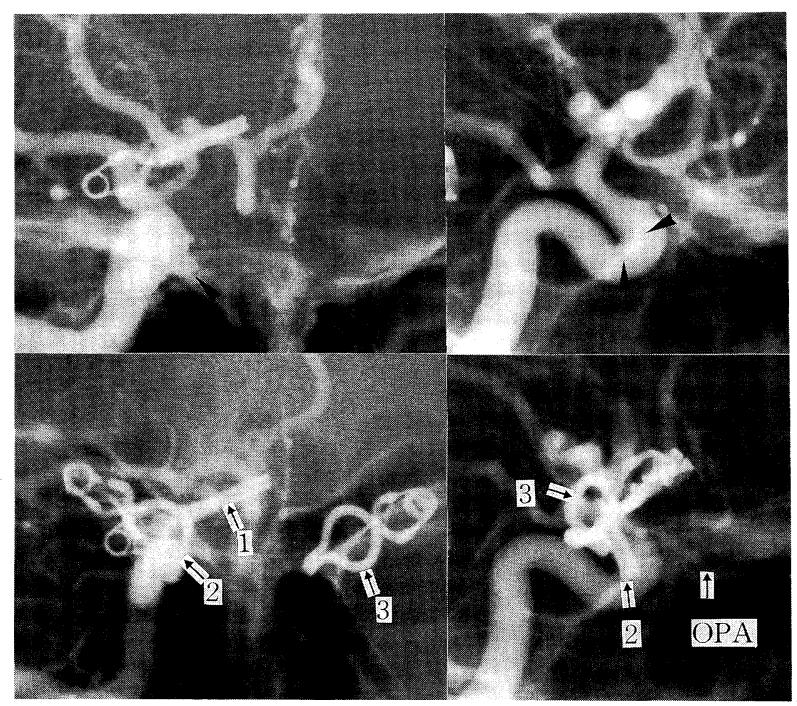

Fig. 7-1 Case 2. Right Carotid cave aneurysm. Right carotid angiograms. (Basilar and left intradural aneurysms were previously clipped) Upper: Preoperative angiograms on A-P and lateral views. Note that the aneurysm is located proximally to the ophthalmic artery and at the surgical genu on the lateral view. Arrowheads indicate the aneurysm. Lower: Postoperative angiograms. Note that the site of the aneurysm is precisely confirmed by the position of the clip blades. 1: clip for basial aneurysm, 2: clip for the carotid cave aneurysm, 3: clip for opposite intradural aneurysm. OPA: ophthalmic artery.

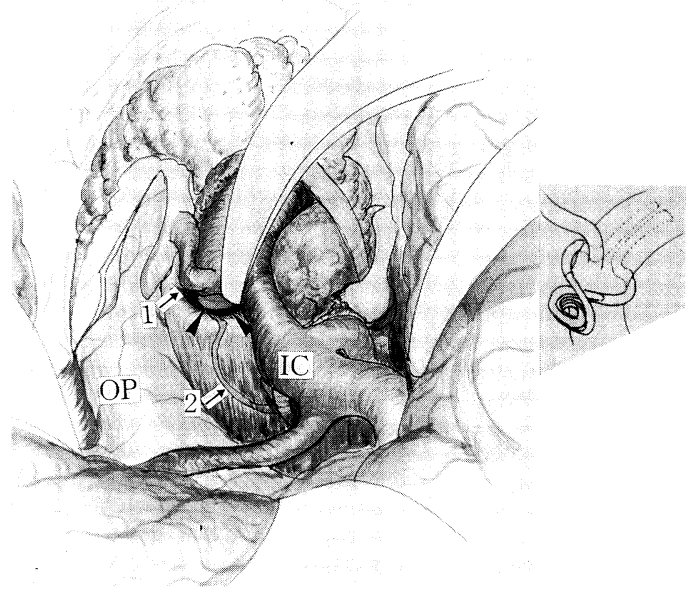

Fig. 7-2 Operative drawing. Abbreviations are the same as in Fig. 1. Arrow heads indicate aneurysm.

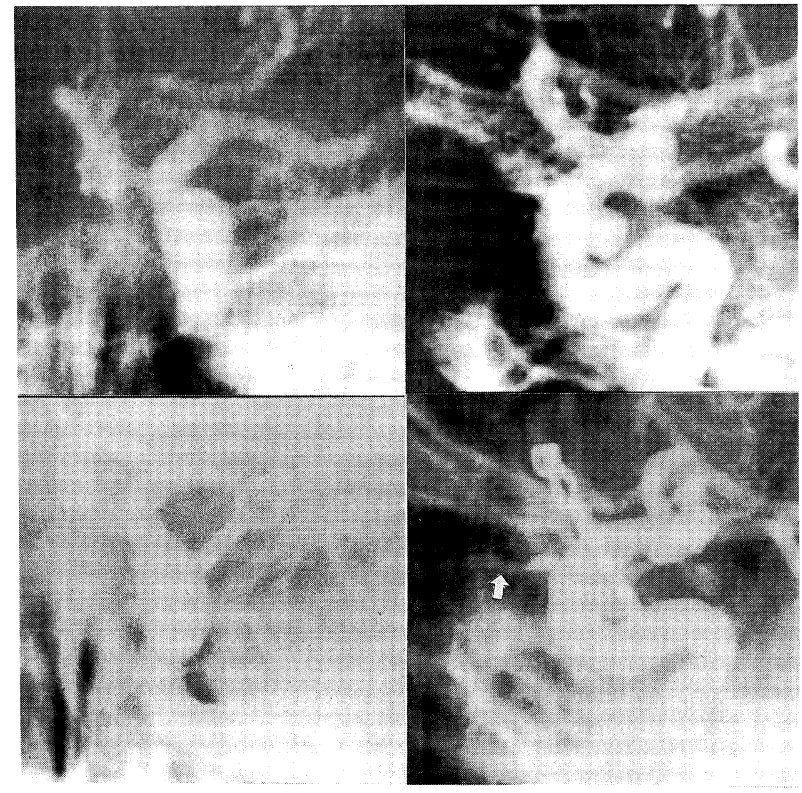

Fig. 8-1 Case 3. Left carotid angiograms of infraclinoid aneurysm. Preoperative (upper) and postoperative (lower) angiograms on A-P and lateral views. Note that on the lateral view the aneurysm is located proximally to the ophthalmic artery (arrow) and at the angiographical genu, while on the A-P view the aneurysm is superimposed with the ICA unlike in a carotid cave aneurysm.

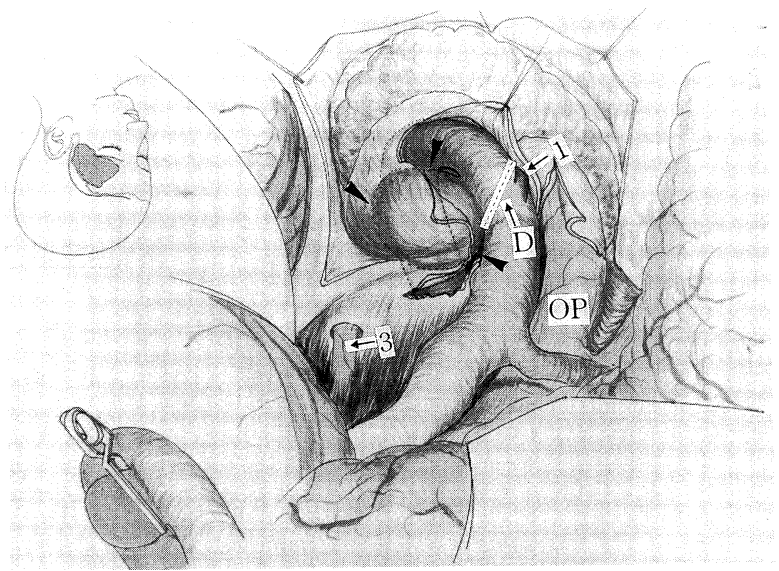

Fig. 8-2 Operative drawing. Note that the aneurysm is located extradurally and oppositetos the carotid cave. The medial triangle is partially opened. Abbreviations are the same as in Fig. 1. Arrowheads indicate aneurysm. 
にinfraclinoid space の開放により，dural ring を全周にわ たって開放することが最も重要な手術手技である。前床突 起切除のみ ${ }^{20)}$ では dural ring の開放は不可能で動脈瘤の全 貌を確認することはできない. 言いかえればJuxtaDURAL RING aneurysm は十分な前床突起の切除, 視神 経管の開放, dural ring の開放を行わなければクリッピン グ不可能といえる.

前床突起切除の方法については硬膜外, 硬膜内, あるい は硬膜内外併用 ${ }^{2)}$ によるものがあるが, 我々は硬膜内操作 にて行っている. 硬膜内操作の方が解剖学的位置関係が確 認しゃすく，動脈瘤損傷の危険性も少ないと考えている. 前床突起および視神経管の drillingにあたってはサイラス ティックシート(シリコンシート)で視神経, 内頸動脈など を保護すると安全である ${ }^{12)}$.

infraclinoid space は clinoid space とも呼ばれているが 19), anteromedial triangle ${ }^{3)}$ とほぼ同じである。 infraclinoid spaceを開放し genu および axilla を確保することは この部での temporary clipping にそなえるためにも必要な 操作である ${ }^{8)}$. この部が容易に確保されるならば，あらか じめ頸部で内頸動脈を確保することは不要とも思われるが, infraclinoid segment が確保されるまでは, 頸部で内頸動 脈を確保することが安全である。実際にはinfraclinoid segmentに temporary clip をおいて，さらにネッククリッ ピングすることは，この部分が狭いために容易ではない. また axilla は動脈瘤のクリッピングに際して重要な部位で, 特に腹側型の動脈瘤ではこの部を確保し，リングクリップ のブレイドがこの部にはいることを確認することが内頸動 脈を閉塞させないために大切である. surgical genuを十 分露出させるためには必然的に視神経管および carotid groove と視神経管の隔壁である optic strut を削ることに なる、視神経管および dura propriaの開放, 眼動脈の遊 離は動脈瘤ネックの露出やクリッピングに際して視神経圧 排を安全に行うために必須である.

内頸動脈 $\mathrm{C}_{2}$ 部分では内頸動脈が外方に, 視神経が内方 に位置しているが, 内頸動脈硬膜輪近傍では内頸動脈と視 神経との位置関係は，上下に重なるようになっているため， 通常の内頸動脈瘤に対する手術の場合よりさらに頭部を対 側に回転させる必要がある. 我々はだいたい 45 度前後, 頭部を対側に回転させている。

Juxta-DURAL RING aneurysm における基本的手術手 技は dural ring 近くまで発育した内頸動脈の大型あるいは 巨大動脈瘤の手術に掞いても動脈瘤ネックの近位側を確保 するのに有用な手技である.

\section{2. 各動脈瘤の特徵}

intradural aneurysm は従来の眼動脈瘤のうち特にdural ringに近接するもので, 血管写側面像では眼動脈分岐部 より遠位側に位置する(Fig. 4). Yasargil, Fox, Nutik ら ${ }^{6)}$ 13) 14) 18) 21) のいう ventral internal carotid aneurysm, paraclinoid aneurysm にほぼ相当するが, これらの動脈瘤の中 には carotid cave aneurysmが一部含まれている.

carotid cave aneurysm は解剖学的には硬膜内に発育す る動脈瘤で, 血管写側面像では眼動脈分岐部より近位側で 内頸動脈サイフォン部の最大弯曲部に位置する(Fig. 4). 正面血管写像では内側に向いているのが特徵である (Fig.5-1，7-1）。この部の動脈瘤は従来海綿静脈洞内動脈 瘤とされていたものであり，手術に際しては動脈瘤ネック の確認ができず手術不可能とされていたものである.

infraclinoid aneurysm は従来の海綿静脈洞内動脈瘤に含 まれるが, 前床突起を切除して初めて確認される. 血管写 側面像では最大弯曲部よりわずかに近位側に認められる (Fig. 4). Perneczky ら ${ }^{17) 18)}$ のいう infraclinoidal あるいは infraclinoid anuerysm にほぼ相当するが，これらの中には 我々のいう carotid cave aneurysm が一部含まれている.

Juxta-DURAL RING aneurysmに扔ける，手術所見と 血管写所見を比較してみると， surgical genu と angiographical genu $\left(\mathrm{C}_{3}\right.$ 部)には，位置のずれが認められるが, これは術野の方向が真上からではなく，前頭側から見てい るためと考えられる，逆に血管写で $\mathrm{C}_{3}$ 部に認められる動 脈瘤は，正面像で内側を向いていれば，海綿静脈洞内動脈 瘤ではなく，硬膜内由来の carotid cave aneurysmである. 我々の提唱したJuxta-DURAL RING aneurysm に該当す る動脈瘤に対して種々の approach が行われているが7) 16), pterional approachによる前述の手術手技で十分クリッピ ング可能である.

\section{結語}

Juxta-DURAL RING aneurysm の手術では,この部の 外科解剖学的関係から基本的に共通した手術手技が必要と される.この部の外科解剖を熟知し, 手術手技的には pterional approachにて, 硬膜内より前床突起の完全切除, 視神経管の unroofing, infraclinoid space の開放, 十分な dural ring の開放を行うことにより比較的安全かつ容易に クリッピング可能である. またこれらの手術操作中におけ る, 海綿静脈洞からの出血に対してはオキシセル綿などの パッキング，および頭部挙上により容易に止血可能である. 


\section{文献}

1) Dawson BH: The blood vessels of the human optic chiasma and their relation to those of the hypophysis and hypothalamus. Brain 81: 207-217, 1958

2) Dolenc V: A combined epi- and subdural direct approach to carotid-ophthalmic artery aneurysms. J. Neurosurg 62: 667-672, 1985

3) Dolenc VV: Anatomy and Surgery of the Cavernous Sinus, Springer, Wien, 1989, pp 9-25

4) Fischer E: Die Lageabweichungen der vorderen Hirnarterie im Gefässbild. Zentralbl Neurochir 3: 300-312, 1938

5) Fox JL: Microsurgical treatment of ventral (paraclinoid) in ternal carotid aneurysms. Neurosurgery 22: 32-39, 1988

6) Gibo H, Kobayashi S, Kyoshima K, et al: Microsurgical anatomy of the arteries of the pituitary stalk and gland as view from above. Acta Neurochir (Wien) 90: 60-66, 1988

7）白馬 明, 坂本博昭：各部位の脳動脈瘤の手術 3)内頸動 脈 C2 および C3 の部位より生じた動脈瘤, 脳動脈瘤の治療, 現代医療社, 1990, pp 117-128

8) Knosp E, Müller G, Perneczky A: The paraclinoid carotid artery: Anatomical aspects of a microneurosurgical approach. Neurosurgery 22: 896-901, 1988

9) Kobayashi S, Kyoshima K, Gibo $\mathrm{H}$, et al: Carotid cave aneurysms of the internal carotid artery. J. Neurosurg 70: 216-221, 1989

10）小林茂昭, 宜保浩彦：内頸動脈窩動脈瘤の外科解剖。顕微 鏡下手術のための脳神経外科解剖, 第2回微小脳神経外科解 剖セミナー講演集, 1988, pp 64-69

11) Kyoshima K, Kobayashi S: Carotid cave aneurysms of the internal carotid artery. Intracranial Aneurysms and Arteriovenous Malformations, Nagoya University COOP Press, Nagoya, 1990, pp 197-207

12）京島和彦，小林茂昭：頭蓋底部髄膜腫の手術. Clin Neurosci 8: $114-115,1990$

13) Nutik S: Carotid paraclinoid aneurysms with intradural origin and intracavernous location. J Neurosurg 48: 526-533, 1978

14) Nutik SL: Ventral paraclinoid carotid aneurysms. J Neurosurg 69: 340-344, 1988

15) Nutik SL: Removal of the anterior clinoid process for exposure of the proximal intracranial carotid artery. J Neurosurg 69: 529-534, 1988

16）大西英之, 下村隆英, 藤田豊久：ほか：海綿静脈洞内動脈 瘤の直達手術. Neurosurgeons 8: 210-221, 1989

17) Perneczky A, Knosp E, Vorkapic P, et al: Direct surgical approach to infraclinoidal aneurysms. Acta Neurochir (Wien) 76: 36-44, 1985

18) Perneczky A, Knosp E, Czech TH: Para- and infraclinoid aneurysms: Anatomy, surgical technique, and report of 22 cases. In: Dolenc VV (ed), The Cavernous Sinus, Springer, Berlin, 1987, pp 252-271

19) Sekhar LN, Burgess J, Akin O: Anatomical study of the cavernous sinus emphasizing operative approaches and related vascular and neural reconstruction. Neurosurgery 21: 806-816, 1987

20）堤 一生, 塩川芳昭, 及川明博, ほか：内頸動脈 $\mathrm{C}_{2} \sim \mathrm{C}_{3}$ 移 行部の剝離について。脳卒中の外科 18: 40-43, 1990

21) Yasargil MG, Fox JL: The microsurgical approach to intracranial aneurysms. Surg Neurol 3: 7-14, 1975 